Research Article

\title{
Determinants Influencing the Adoption of Rice Intensification System among Smallholders in Mwea Irrigation Scheme, Kenya
}

\author{
Francis Kadipo Kaloi $\mathbb{D}^{1}{ }^{1}$ Hezron Nyarindo Isaboke, ${ }^{1}$ Charles Nyambane Onyari, ${ }^{2}$ \\ and Lucy Karega Njeru ${ }^{3}$ \\ ${ }^{1}$ Department of Agricultural Economics and Extension, University of Embu, P.O Box 6, Embu 60100, Kenya \\ ${ }^{2}$ Department of Land and Water Management, University of Embu, P.O Box 6, Embu 60100, Kenya \\ ${ }^{3}$ Department of Agricultural Economics, University of Nairobi, P.O Box 29053-00625, Nairobi, Kenya \\ Correspondence should be addressed to Francis Kadipo Kaloi; kadipo.francis@embuni.ac.ke
}

Received 24 February 2020; Revised 6 January 2021; Accepted 3 March 2021; Published 16 March 2021

Academic Editor: Jiban Shrestha

Copyright (c) 2021 Francis Kadipo Kaloi et al. This is an open access article distributed under the Creative Commons Attribution License, which permits unrestricted use, distribution, and reproduction in any medium, provided the original work is properly cited.

\begin{abstract}
Rice farming has received considerable attention in developing countries and particularly in Kenya due to its impact on smallholders' income and food security. Irrigated rice is the largest consumer of water, and its sustainability is threatened by water shortage. This has necessitated the development of alternative irrigation water technologies, such as the system of rice intensification (SRI), which are efficient in water use with improved yields. This study analyzed the determinants of adoption of SRI in the Mwea Irrigation Scheme where stratified sampling was used to obtain 364 smallholder rice farmers. A semistructured questionnaire was used to collect primary data, which was then analyzed using a binary logistic regression model. The results showed that age $(-0.3 \%)$ was significant but with a negative effect on adoption of SRI. Farm size (2.499\%), household size $(1.895 \%)$, distance from the canal (1.354\%), off-farm work (3.953\%), access to credit services $(8.714 \%)$, access to extension services $(7.809 \%)$, and years in rice farming $(0.409 \%)$ were found positively and significantly influencing factors to the adoption of SRI. Therefore, this study concludes that smallholders attempt to improve rice productivity through adoption of SRI should give a special priority to all significant factors.
\end{abstract}

\section{Introduction}

Rice (Oryza sativa L.) is one of the most important food crops for more than $50 \%$ of the world population [1] and significantly influences food security in most countries [2]. About 160 million hectares are estimated to be under rice production globally with an approximate annual production of approximately 500 million metric tons [3]. The demand for irrigation water exceeds the amount of water available for rice irrigation in Kenya [4]. Therefore, alternative practices that reduce water use need to be put in place to enhance sustainable rice production [5].

Various methods have been used to reduce farm input use in rice production [6]. One of the most tried methods was the Green Revolution in Asia, which involved a series of research and technology transfer initiatives [7]. According to [8], the
Green Revolution involves the development of high-yielding varieties of cereal grains and modernization of farmland management techniques. The innovation was very effective and successful in Asia whereby many farmers were able to adopt the technology $[9,10]$. However, the Green Revolution was not able to help many African countries due to limited infrastructure and financial constraints [6]. The system of rice intensification (SRI) was developed about 30 years ago and has been reported to offer an opportunity for reducing water use while maintaining high yields. According to [11], SRI is a concept on the manipulation of agronomic practices to attain higher rice yields with the use of minimal resources such as agrochemicals, seeds, and water (no continuous flooding in SRI as compared to traditional methods). SRI is gaining popularity in all rice-growing areas of the world and that farmers can grow more rice with less water input [7]. 
The key components of SRI include water management which is practiced by keeping the soil well-drained rather than continuous flooding and saturated during the vegetative growth period. The SRI modifies farm practices for managing water use, nutrients, and soils. The two possibilities suggested for water management in SRI involve the application of a small quantity of water daily but leaving the fields dry for short periods (2-7 days) to the point of surface cracking. The other one is flooding and drying the fields for alternating periods of 3-6 days each [12]. The second component is the planting method which involves spacing configurations and the age of seedlings. In SRI, seedlings are transplanted 8-15 days after germination [13]. Some studies suggest a line spacing of $30 \mathrm{~cm} \times 30 \mathrm{~cm}$. The spacing could be based on the local edaphic conditions but it has to facilitate weeding [14]. The third component is weed control which is best done ten days after transplanting and then weeding every ten days until canopy closure [13]. The fourth component is soil fertility management. Most farmers use compost or organic manure but the amount applied varies in terms of its availability and also because there is no fixed recommended rate to follow [13].

Most of the recent and previous studies have shown that farm characteristics, household characteristics, and institutional factors have a significant influence on the adoption of farming technologies [15]. According to Danso-Abbeam et al. [16], the age of the household size, level of experience, farm workshop attendance, the number of years in formal education, availability of labour, and extension contact influence the adoption of improved maize varieties. Similarly, Gershon et al. [17] reported that farmers who managed the postharvest losses were young, had formal education, and had fewer household members. A study conducted by Anang and Yeboah [18] established that years of education, credit access farmer experience, and geographical location were the factors determining the income from the off-farm work. The welfare impacts of SRI revealed that all combinations of SRI individually and as a group (water management, plant management, and soil management) had a positive impact on productivity as reported by [19]. Similarly, according to [20], farmer's location income, interest rates, rice farming experience, and the distance to the source of credit are statistically significant determinants of the amount of credit received.

According to Noltze (2012), SRI seemed to be adopted more on plots and by farmers with less than average yields. The results also noted that SRI may not be beneficial when compared to conventional flooding (CF) rice grown under favorable conditions and with the best management practices. There exists a threshold for the effect of education on agricultural productivity change as reported by Fung-Mey Huang [21] and Myint and Napasintuw [22]. According to [23], households who used improved seed varieties tend to be different from those that do not. They also have a higher consumption expenditure. The results indicate the potentials of the improved seed varieties in helping the households in especially in rural areas increasing their welfare.

Many empirical studies have investigated the issue of adoption (see, e.g., [23], Noltze (2012), and Varma [19].
However, alternative production practices such as SRI have not yet been fully investigated especially on adoption. Previous studies on SRI in the Mwea Irrigation Scheme include studies of Ndiiri et al. [6,24]. Studies such as [6] focused on the constraints and the returns associated with SRI while the study [24] focused on the perceptions of SRI. From these studies, little has been done or investigated on determinants of SRI in the Mwea Irrigation Scheme. The knowledge on SRI is still scanty especially on the application of econometric modeling. Therefore, this study provides a strong case of the argument of using SRI to generate information on determinants of SRI adoption with a view of driving policy recommendations and filling the information gap in Kenya.

\section{Materials and Methods}

2.1. Study Area and Methods of Data Collection. The study was conducted in the Mwea Irrigation Scheme (MIS) in Kirinyaga County, Kenya (Figure 1). The scheme is located in the central part of the country. It occupies the lower altitude zones of the region with expansive low marshy areas. The altitude ranges from 1,000 to 2,200 $\mathrm{m}$ above the sea level, with temperatures ranging between $15^{\circ} \mathrm{C}$ and $30^{\circ} \mathrm{C}$. The area experiences bimodal types of rains with the short rains occurring from October to December and the long rains occur between March and May. The main agricultural activity is monocropping of rice grown in paddies that are irrigated for six months. The main sources of water for the scheme are the River Nyamindi and River Thiba which are tributaries of the River Tana. There are approximately 7320 households within the main scheme [25].

A field survey was carried out using a semistructured questionnaire to get quantitative data from the smallholder rice farmers. Additionally, key informant interviews were undertaken for the qualitative data. Well trained enumerators were employed to collect data during the study period. Following this, respondents were selected using a stratified random sampling technique. This was done with the aid of the rice units as strata. 12 units were randomly selected from the 20 units which are within the 4 major rice-producing blocks in the irrigation scheme. The major blocks include Karaba, Tebere, Wamumu, and Thiba. A total of 30 smallholder rice farmers were selected per unit, and about 91 per block were sampled to give a total of 364 respondents.

2.2. Theoretical Review. Smallholder farmer's perception is to maximize on their perceived utility. The study was based on the subjective expected utility framework. The individual expected utility of innovation can be approximated in the following equations:

$$
\begin{aligned}
\operatorname{SEU}(\pi) & =\sum_{i} p_{i}^{t} U(\pi i) \\
U(\pi) & =\frac{\pi^{1-\mathrm{RRA}}}{1-\mathrm{RRA}}
\end{aligned}
$$

where $p_{i}$ is the probability of the state of nature $i$ for the profit $\left(\pi_{i}\right)$, RRA is the relative risk aversion coefficient, and 

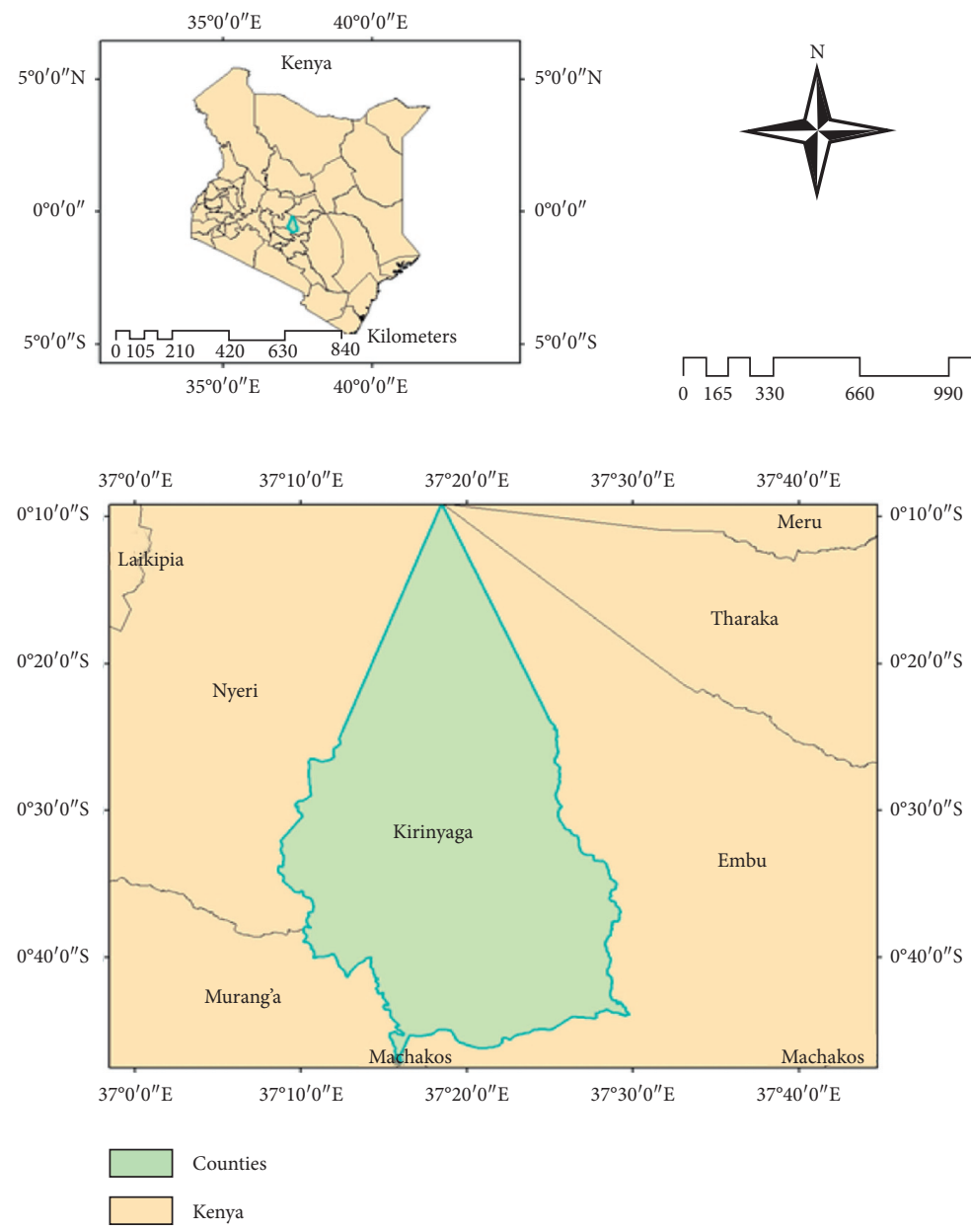

Figure 1: Map of the Mwea Irrigation Scheme in Kirinyaga County.

SEU is the subjective expected utility. When farmers have a choice, they do select the alternative with the highest utility (equation (3)). Based on the random utility theory, the global utility of a system is composed of the utility of each characteristic of the cropping system. Although profit could be one of the characteristics, farmers also maximize their utility based on other factors such as agronomic and technical:

$$
U_{k}>U_{j} \text {, }
$$

where

$$
U\left(t_{1}, t_{2}, \ldots, t_{r}\right)+\varepsilon,
$$

where $t_{1}, t_{2} \ldots t_{r}$ corresponds to the $r$ characteristics of innovation while the error term $(\varepsilon)$ depicts the individual determinants.

2.3. Empirical Model. To determine the selected determinants of SRI adoption, a binary logistics regression model was used. The smallholders were classified as either as the adopters whose value was equal to 1 or the nonadopters whose value was equal to 0 [26].

The probability function for the farmers who choose to adopt SRI can be represented as a latent variable $y_{1}^{*}$, a function of the observed explanatory variables, $x_{i}$ and an error term $\varepsilon_{i}$ :

$$
y_{1}^{*}=x_{i}^{\prime} \beta+\varepsilon_{i} .
$$

SRI adoption can be expressed by a binary model with two options: if yes, $y=1$, and otherwise, $y=0$; the probability of $y=1$ is expressed by a formula as indicated in equation (2):

$$
P_{r}\left(Y_{i}=1 l x_{i}\right)=G\left(x_{i}, \beta\right) .
$$

$G$ which is a function with two values, zero or one, can be expressed as follows:

$$
\operatorname{Pr}(\text { Adopt }=1)=G\left(\beta_{o}+\beta_{1} x_{1}+\cdots \beta_{k} x_{k}+e\right) .
$$

$\operatorname{Pr}($ Adopt $=1)$ determines the probability of adopting SRI by the smallholder farmer given the predictor variables $x_{i}, \ldots, x_{k}$. The $\beta_{o}$ is the intercept, and $\beta_{1}, \ldots, \beta_{k}$ are the estimated parameters for the predictor variables while $e$ is the error term:

$$
G(z)=\frac{\exp (z)}{1+\exp (z)}
$$

The predictor variables were the gender of the household head $\left(X_{1}\right)$, age of the smallholder farmer $\left(X_{2}\right)$, marital 
status $\left(X_{3}\right)$, education level $\left(X_{4}\right)$, household size $\left(X_{5}\right)$, farm size $\left(X_{6}\right)$, monthly income $\left(X_{7}\right)$, off-farm work $\left(X_{8}\right)$, years spent in rice farming $\left(X_{9}\right)$, access to extension services $\left(X_{10}\right)$, access to credit $\left(X_{11}\right)$, and the distance from the canal $\left(X_{12}\right)$. Table 1 provides the description and measurement of the predictor variables.

The Breusch-Pagan test was used to test the presence of heteroscedasticity. The test compared the alternative hypothesis and the null hypothesis. The results showed that the value of the chi-square statistics is less than 0.05 . Therefore, the null hypothesis was rejected at a $5 \%$ level of significance (Table 2).

\section{Results and Discussion}

3.1. Characteristics of the Respondent according to Adoption Status. The mean age of the respondent was 42 years with a relatively high proportion of middle age rice farmers among the respondents as shown in Table 3. The results were significant implying that young farmers were actively involved in farm operations. Furthermore, the results showed that $56.33 \%$ of adopters had obtained primary education, $79.17 \%$ obtained secondary level and $97.37 \%$ had achieved tertiary education. Among the nonadopters, $43.67 \%$ obtained primary education, $20.83 \%$ achieved secondary education, and $2.63 \%$ had tertiary education. The results were significant implying that the majority of the adopters had acquired formal education as compared to nonadopters. This confirms the findings of [27]. The results further showed that the mean household size for the adopters was 4.12 and 5.12 for the nonadopters. The results were significant revealing that the nonadopters had relatively largesized households than the nonadopters. Analysis of the occupation showed that $88.42 \%$ of the adopters were undertaking casual work and $3.86 \%$ were livestock keepers, while $91.43 \%$ of the nonadopters were casual workers and $75.57 \%$ were livestock keepers. The results were significant showing that most of the nonadopters of SRI were undertaking off-farm occupations.

Furthermore, the study findings revealed that the average distance from the canal for the adopters of SRI was $5 \mathrm{~km}$ and for the nonadopters, and it was $4 \mathrm{~km}$. The results were significant, implying that the adopters were far from the water source as compared to nonadopters. Therefore, the adopters needed to be efficient in water usage due to difficulty and cost of accessing water from the main canals.

The study assessed the farm size of the respondents. The mean farm size for the SRI farmers was $1.5 \mathrm{Ha}$ and $2.1 \mathrm{Ha}$ for the nonadopters. The findings were significant confirming that the nonadopters had large holdings as compared to adopters of SRI. The monthly income of the respondents was tabulated in Kenya shillings (KES). The average monthly income of the adopters was KES 40,374.52 while the average monthly income for the nonadopters was KES 33,761.90. The results were significant. This implied that SRI adopters had a higher monthly income than the nonadopters.

The study assessed the years that farmers were involved in rice farming. The results showed that the adopters of SRI have spent 6.2 years in rice farming while the nonadopters have spent 8.1 years in rice farming. The mean difference in the two groups was significant indicating that adopters were less experienced in rice farming as compared to the nonadopters. The results agree with the findings of [19], who reported that the number of years spent on rice farming reduced the adoption of new agricultural technologies. This means that a majority of the nonadopters are accustomed to the old way of rice farming while the adopters are willing to take up the challenge of a new and promising production technology. The results further showed that $92.66 \%$ of the adopters received extension services while $7.34 \%$ did not. For the nonadopters, $69.52 \%$ reported that they received extension services while $30.48 \%$ did not. The results were significant indicating that most adopters receive extension services as compared to nonadopters. The study asked the respondents to indicate whether they accessed credit services in their rice farms. The results showed that $33.98 \%$ of the adopters received credit services while $66.02 \%$ reported that they did not receive credit services. It was observed that $91.43 \%$ of the nonadopters reported that they did not receive credit services while $8.57 \%$ did. The results were significant implying that the majority of the smallholders did have access to credit within their locality.

3.1.1. Determinants of Adoption of SRI. The determinants of SRI adoption were analyzed using a binary logistic regression model. The smallholder farmers were classified as either adopters or nonadopters of the SRI technology compared to conventional flooding (CF). The likelihood ratio estimates in Table 4 show that all the chi-square statistics are significant at $1 \%$ $(p<0.001)$. This shows that the binary logistics model was the most appropriate in explaining the determinants of SRI adoption. The model accounted for $77.8 \%$ of the variation between SRI and CF. 8 out of the 12 variables were highly significant.

The estimated coefficient for age had a negative effect on the adoption of SRI. This indicated that the adoption of SRI decreased with the age of the farmer. The results implied that a unit increase in the age of the farmer decreased the likelihood of adopting SRI by $0.3 \%$. Older farmers may be more conservative, and they do not want to change their farming practices from CF to SRI while the younger counterparts preferred SRI due to their familiarity with the technology information. Furthermore, the results show that younger farmers remain essential as the primary audience for the adoption of new agricultural technologies such as SRI. These results agree with the findings of [28], Varma [29], and Chuchird et al. [30-32] who reported a negative relationship between age and adoption of farming technologies.

Household size was found to have a significant and a positive relationship with the adoption of SRI. The findings show that family size influences the adoption of SRI positively and a unit increase in household size will increase the adoption of SRI by $4.5 \%$. This shows that SRI is labour intensive and therefore large families attract labour required in nursery preparation, land leveling, transplanting of young seedlings, and weeding. The findings corroborate those of Kinuthia [23] who reported similar results in Uganda and Tanzania. 
Table 1: Description of variables.

\begin{tabular}{|c|c|c|}
\hline Variable & Description & Measurement \\
\hline Age & Age records the age of the farmer & Number of years \\
\hline Gender & Gender is a variable that indexes the gender of the adopter & $\begin{array}{c}1 \text { for male } \\
0 \text { for female }\end{array}$ \\
\hline Household size & Records the number of family members living in the same household & $\begin{array}{c}\text { Number of family members } \\
\text { 1. Primary education }\end{array}$ \\
\hline Education level & Households' level of education & $\begin{array}{l}\text { 2. Secondary education } \\
\text { 3. Postsecondary }\end{array}$ \\
\hline Off-farm occupation & The variable measures whether the household has any other occupation & $\begin{array}{l}\text { 1. Casual work } \\
\text { 2. Livestock keeping } \\
\text { 3. Others }\end{array}$ \\
\hline Farm size & This variable indexes households with farms under rice production & Number of hectares $(\mathrm{Ha})$ \\
\hline Access to extension services & This variable indexes trainings on SRI & $\begin{array}{l}\text { 1. Access extension service } \\
\text { 0. Does not access }\end{array}$ \\
\hline Monthly income & Measures the monthly income for the households & $\begin{array}{l}\text { Kenya shillings per } \\
\text { household. (KES) }\end{array}$ \\
\hline Access to credit & Whether households access credit & $\begin{array}{c}\text { 1. Access } \\
\text { 0. Does not access }\end{array}$ \\
\hline Distance from the canal & This variables measures distance from the main canal in kilometers & Distance in kilometers (KM) \\
\hline
\end{tabular}

Authors' source, 2020.

TABLE 2: Testing for heteroscedasticity.

Breusch-Pagan/Cook-Weisberg test for heteroscedasticity

Ho: constant variance

Variables: fitted values of SRI_Adoption

chi2 $2(1)=4.38$

Prob $>$ chi $2=0.0364$

Source: authors' calculation, 2020.

Farm size was found to have a positive and significant effect on adoption of SRI. This means that farm size increases the adoption of SRI by $5.9 \%$. Farmers with large farms are likely to experiment with new technologies on small fields before adopting in a large scale. This observation agrees with studies by [33] and Ghimire et al. $[23,26]$ who reported that owning more farmlands is correlated with the adoption of agricultural technologies.

The significant and positive results of off-farm work shows that participation in off-farm work increases the adoption of SRI by $9.3 \%$. The results revealed that smallholders who are engaged in other off-farm activities are likely to adopt SRI than those who concentrated entirely on rice farming. Also the income received from off-farm activities was used to meet some of the farm operation cost in SRI farming. This findings agree with the studies of $[34,35]$ who found that off-farm income increased adoption of production technologies. Similarly, Kaloi et al. [36] found that participation in off-farm activities positively affects the adoption of agricultural technologies. This may be due to frequent access to information flow that is important in understanding the new agricultural technologies.

Experience in paddy farming significantly increases the adoption of SRI by $0.97 \%$. The results imply that an increase in farmer's experiences increases the adoption of SRI technology. As the experience in rice farming increases, smallholders acquire additional skills and knowledge on innovative agricultural practices, thus a positive relationship between farmer experience and adoption of SRI technology. The results agree with the findings of [37] who reported that farmers endowed with knowledge and experience easily understand or grasp the new technologies.

Moreover, the econometric model results revealed that access to extension services increases the adoption of SRI by 94.5\%. The results imply that farmers who have access to extension have a higher probability of adopting SRI since extension services serve as an important source of information on agricultural production. Farmers who have significant extension contacts have better chances to be aware of various management practices that they can use to increase production. Similar results were reported by [38], who found out that access to the extension has a positive relationship with the adoption of farming practices. Also, Ahmed et al. [1] indicated that access to extension services positively affects the adoption of maize varieties.

As it was hypothesized, access to credit services had a positive relationship with adoption of SRI. Access to credit facilities increases the adoption of SRI by $20.6 \%$. Credit services increases the purchasing power of agricultural inputs. The results agree with the findings of [33] who reported that credit is an important determinant in the adoption of agricultural technologies.

The results further show that distance from the canal was significant at $5 \%$ with a positive coefficient. Therefore, an increase in the distance from the canal increased the adoption of SRI by $3.2 \%$. This implies that as the distance increases, less water is available for the SRI farmers who then become more efficient in using their inputs such as water in rice production. This implied that those farmers who were far away from the canals had higher adoption status than those near the canals. Water shortage is a critical constraint in the Mwea Irrigation Scheme. Before the inception of SRI, water shortage had forced some farmers to grow rice in nonflooded conditions. Similar results were reported by 
TABLE 3: Descriptive analysis for the adopters and nonadopters of SRI.

\begin{tabular}{|c|c|c|c|c|}
\hline Variable & $\begin{array}{c}\text { Adopters } \\
n=259\end{array}$ & $\begin{array}{c}\text { Nonadopters } \\
n=105\end{array}$ & $\begin{array}{c}\text { Pooled mean } \\
n=364\end{array}$ & $t /$ chi value \\
\hline Age (mean age) & 42 & 41 & 41 & $52.40 * * *$ \\
\hline \multicolumn{5}{|l|}{ Gender } \\
\hline Male (\%) & 22.39 & 31.43 & 38.1 & 3.25 \\
\hline Female $(\%)$ & 77.61 & 68.57 & 73.09 & \\
\hline \multicolumn{5}{|l|}{ Education level (\%) } \\
\hline Primary & 56.33 & 43.67 & 43.41 & $159.60 * * *$ \\
\hline Secondary & 79.17 & 20.83 & 46.15 & \\
\hline Postsecondary & 97.37 & 2.63 & 10.44 & \\
\hline Household size & 4.12 & 5.2 & 5.0 & $48.08 * * *$ \\
\hline Farm size $(\mathrm{Ha})$ & 1.5 & 2.1 & 1.8 & $15.85 * * *$ \\
\hline Monthly income (KES) & 40374.5200 & 33761.9000 & $37,068.21$ & $47.70 * * *$ \\
\hline \multirow[t]{2}{*}{ Years in paddy farming } & 6.2 & 8.1 & 7.1 & $27.08^{* * *}$ \\
\hline & & & & $33.21 * * *$ \\
\hline \multirow[t]{2}{*}{ Access to extension services } & 92.66 & 69.52 & 81.09 & \\
\hline & 7.34 & 30.48 & 18.91 & \\
\hline Casual work & 88.42 & 91.43 & & \\
\hline Livestock keeping & 3.86 & 7.57 & 89.93 & $11.36^{* * *}$ \\
\hline Others & 7.72 & 1.0 & 5.72 & \\
\hline \multirow{2}{*}{ Credit access } & 33.98 & 91.43 & 62.705 & $98.65 * * *$ \\
\hline & 66.02 & 8.57 & 37.29 & \\
\hline Distance to canal & 5.4788 & 4.1714 & 4.83 & $3.59 * * *$ \\
\hline
\end{tabular}

Source: authors' calculations, 2020 . Note: ${ }^{* *}$ denotes significance at $1 \%$.

TABLE 4: Binary logistic regression results.

\begin{tabular}{lccc}
\hline Variables & Coefficients & $Z$ values & $\begin{array}{c}\text { Marginal } \\
\text { effects }\end{array}$ \\
\hline Gender & $1.017(0.679)$ & 1.5 & 0.031 \\
Age & $-0.138(0.043)$ & $-3.22^{* * *}$ & -0.003 \\
Marital status & $-3.737(1.144)$ & -3.27 & -0.089 \\
Education & $-0.378(0.661)$ & -0.57 & -0.009 \\
Household size & $1.895(0.322)$ & $5.88^{* * *}$ & 0.045 \\
Farm size & $2.499(0.498)$ & $5.02^{* * *}$ & 0.059 \\
Monthly income & $0.000(0.000)$ & 0.69 & 0.001 \\
Off-farm work & $3.953(0.847)$ & $4.67^{* * *}$ & 0.093 \\
Years of rice & $0.409(0.121)$ & $5.8^{* *}$ & -0.0097 \\
farming & $7.809(1.659)$ & $4.71^{* * *}$ & 0.945 \\
Extension services & $8.714(1.664)$ & $5.24 * *$ & 0.206 \\
Credit access & $1.354(0.303)$ & $4.47^{* * *}$ & 0.032 \\
Distance from canal & -2.41 & \\
Cons & $-8.316(3.449)$ & -2.41 & \\
\hline
\end{tabular}

Number of obs $=364$; LR $\chi 2(11)=340.60$ Prob $>\chi 2=0.0000$; log likelihood $=-48.378857$; pseudo $R 2=0.7788$. Source: authors' calculations, 2020. Note: ${ }^{* * *}$ and ${ }^{* *}$ significance at $1 \%$ and $5 \%$.

Sinyolo et al. [39], who noted that farmers who were far from the water sources were more efficient in utilizing the resources than farmers who were closer to the water sources.

\section{Conclusion and Policy Recommendations}

The study evaluated determinants of smallholders' adoption of SRI in the Mwea Irrigation Scheme. The study was undertaken to understand the adoption of SRI as a climate-smart technology in rice farming. The econometric results showed that the adoption of SRI increased with the age of the farmer, farm size, household size, credit access, farmer experience, access to extension services, distance from the canal, and off-farm income. The study recommends to the local government and other stakeholders to focus more on the youthful farmers who are more willing to take up new rice farming technologies such as SRI if this practice is to gain prominence in enhancing production of the crop for better food security. This should also apply to smallholder farmers with limited parcels of land who are willing to utilize part of their land for growing rice using SRI. These strategies can best be achieved by the government and other stakeholders in the subsector through enhanced provision of extension services and promoting ease of access to credit facilities to these farmers.

\section{Data Availability}

The data supporting the findings of the study are available upon request from the corresponding author.

\section{Conflicts of Interest}

The authors declare that there are no conflicts of interest.

\section{Acknowledgments}

The authors acknowledge the Higher Education Loans Board (HELB) in Kenya for the scholarship award that funded and supported this research.

\section{References}

[1] H. Ahmed, B. Tetteh Anang, and B. T. Anang, "Impact of improved variety adoption on farm income in Tolon district of Ghana," Agricultural Social Economic Journal, vol. 19, no. 2, pp. 105-115, 2019. 
[2] I. Ara, M. Lewis, and B. Ostendorf, "Understanding the spatially variable effects of climate change on rice yield for three ecotypes in Bangladesh, 1981-2010," Advances in Agriculture, vol. 2017, Article ID 6287156, 11 pages, 2017.

[3] M. Kirby, M.-u.-D. Ahmad, M. Mainuddin, and T. Khaliq, "Agricultural production, water use and food availability in Pakistan: historical trends, and projections to 2050," Agricultural Water Management, vol. 179, pp. 34-46, 2017.

[4] S. O. Salami and K. M. Shikuku, "An analysis of technical efficiency of rice farmers in ahero irrigation scheme, Kenya," Journal of Economics and Sustainable Development, vol. 4, no. 10, pp. 9-16, 2013.

[5] E. K. Denkyirah, "Profitability of rice production: a comparative analysis of system of rice intensification and conventional method in the Kassena-Nankana east district of Ghana," Doctoral dissertation, University Of Ghana, Accra, Ghana, 2015.

[6] J. A. Ndiiri, B. M. Mati, P. G. Home, B. Odongo, and N. Uphoff, "Adoption, constraints and economic returns of paddy rice under the system of rice intensification in Mwea, Kenya," Agricultural Water Management, vol. 129, pp. 44-55, 2013.

[7] K. Sudeep, "System of rice intensification: an analysis of adoption and potential environmental benefits," Master's thesis, Norwegian University of Life Sciences, Ås, Norway, 2011.

[8] S. Rahman, "Climate, agroecology and socio-economic determinants of food availability from agriculture in Bangladesh, (1948-2008)," Sustainability, vol. 9, no. 3, p. 354, 2017.

[9] D. S. Ehiakpor, J. Apumbora, G. Danso-abbeam, and W. Adzawla, "Households' preference for local rice in the upper east region, Ghana," Advances in Agriculture, vol. 2017, Article ID 1812975, 9 pages, 2017.

[10] A. K. Thakur, R. K. Mohanty, R. Singh, and D. U. Patil, "Enhancing water and cropping productivity through Integrated System of Rice Intensification (ISRI) with aquaculture and horticulture under rainfed conditions," Agricultural Water Management, vol. 161, pp. 65-76, 2015.

[11] A. Dobermann, "A critical assessment of the system of rice intensification (SRI)," Agricultural Systems, vol. 79, no. 3, pp. 261-281, 2004.

[12] R. E. Namara, P. Weligamage, and R. Barker, "Prospects for adopting the system of rice intensification in Sri Lanka: A socioeconomic assessment," International Water Management Institute, Battaramulla, Sri Lanka, 2003.

[13] S. Thura, "Evaluation of weed management practices in the system of rice intensification (SRI)," M. Sc thesis, Yezin Agricultural University, Naypyidaw, Myanmar, 2010.

[14] N. Uphoff, A. Saryanarayana, and T. M. Thiyagarajan, "Prospects for rice sector improvement with the system of rice intensification, considering evidence from India," in Proceedings of the The International Rice Conference Held in Bali, pp. 10-14, Bali, Indonesia, 2005 September.

[15] M. Ameh and I. C. Andrew, "Socio-economic factors influencing agricultural loan acquisition among small-scale rice farmers in benue state, Nigeria," International Journal of Innovative Agriculture \& Biology Research, vol. 5, no. 4, pp. 8-17, 2017.

[16] G. Danso-Abbeam, J. A. Bosiako, D. S. Ehiakpor, and F. N. Mabe, "Adoption of improved maize variety among farm households in the northern region of Ghana," Cogent Economics \& Finance, vol. 5, no. 1, Article ID 1416896, 2017.

[17] I. Gershon, K. Ansah, and B. K. D. Tetteh, "Determinants of yam postharvest management in the zabzugu district of northern Ghana," Advances in Agriculture, vol. 2016, Article ID 9274017, 9 pages, 2016.

[18] B. T. Anang and R. W. Yeboah, "Determinants of off-farm income among smallholder rice farmers in northern Ghana: application of a double-hurdle model," Advances in Agriculture, vol. 2019, Article ID 7246176, 7 pages, 2019.

[19] P. Varma, Adoption of System of Rice Intensification and its Impact on Rice Yields and Household Income: An Analysis for India (No. WP2017-02-03), Indian Institute of Management Ahmedabad, Research and Publication Department, Ahmedabad, Gujarat. India, 2017.

[20] T. O. Ojo, "Impact of credit demand on the productivity of rice farmers in south west Nigeria," Journal of Economics and Behavioral Studies, vol. 11, no. 1, pp. 166-180, 2019.

[21] Y.-H. L. Fung-Mey Huang, The Economic Value of Education in Agricultural Production: A Switching Regression Analysis of Selected East Asian Countries, International Association of Agricultural Economists, Beijing, China, 2009.

[22] P. L. Myint and O. Napasintuw, "Economic analysis of paw san rice adoption in Myanmar," Asian Journal of Agricultural Research, vol. 10, no. 5, pp. 175-184, 2016.

[23] B. K. Kinuthia, "The impact of agriculture technology adoption on farmers' welfare in Uganda and Tanzania," 2015.

[24] B. W. Ndirangu, Influence of Rice Intensification System on Rice Production among Small Scale Farmers: Case of Tebere in Mwea, Kirinyaga County in Kenya, University of Nairobi, Nairobi, Kenya, 2015.

[25] K. Go, "Ministry of agriculture national rice development strategy (2008 - 2018). Republic of Kenya, Nairobi," 2008, https://www.jica.go.jp/english/our_work/thematic_issues/ agricultural/pdf/kenya_en.pdf.

[26] R. Ghimire, H. Wen-Chi, and R. B. Shrestha, "Factors affecting adoption of improved rice varieties among rural farm households in Central Nepal," Rice Science, vol. 22, no. 1, pp. 35-43, 2015.

[27] M. K. Gebremariam, C. Vaqué-Crusellas, L. F. Andersen et al., "Measurement of availability and accessibility of food among youth: a systematic review of methodological studies," International Journal of Behavioral Nutrition and Physical Activity, vol. 14, no. 1, p. 22, 2017.

[28] M. Nelson, C. Makate, L. Tamene, P. Mponela, and G. Ndengu, "Adoption of small-scale irrigation farming as a climate-smart agriculture practice and its influence on household income in the Chinyanja Triangle, Southern Africa," Land, vol. 7, no. 2, p. 49, 2018.

[29] P. Varma, "Agricultural technology adoption under multiple constraints: an analysis of system of rice intensification (sri) in india (No. 333-2016-14555)," 2016.

[30] R. Chuchird, N. Sasaki, and I. Abe, "Influencing factors of the adoption of agricultural irrigation technologies and the economic returns: a case study in Chaiyaphum Province, Thailand," Sustainability, vol. 9, no. 9, p. 1524, 2017.

[31] A. W. Cheema, "Allocative and technical efficiency analysis of cassava farming in bitefa village, east miofamo district, middle north timor," Habitat, vol. 28, no. 3, pp. 75-82, 2018.

[32] M. Suvedi, R. Ghimire, and M. Kaplowitz, "Farmers' participation in extension programs and technology adoption in rural Nepal: a logistic regression analysis," The Journal of Agricultural Education and Extension, vol. 23, no. 4, pp. 351-371, 2017.

[33] A. A. Chandio and Y. Jiang, "Factors influencing the adoption of improved wheat varieties by rural households in Sindh, Pakistan," AIMS Agriculture and Food, vol. 3, no. 3, pp. 216-228, 2018. 
[34] G. Danso-Abbeam, M. Armed, and F. Baidoo, "Determinants of consumer preference for local rice in Tamale Metropolis, Ghana," International Journal of Education and Social Science, vol. 1, no. 2, pp. 114-122, 2014.

[35] H. Pereira and R. C. Marques, "An analytical review of irrigation efficiency measured using deterministic and stochastic models," Agricultural Water Management, vol. 184, pp. 28-35, 2017.

[36] F. K. Kaloi, H. N. Isaboke, C. N. Onyari, and L. K. Njeru, "Comparing productivity of rice under system of rice intensification and conventional flooding: a switching regression approach," African Journal of Agricultural Research, vol. 16, no. 10, pp. 1355-1363, 2020.

[37] Y. Kebede, K. Gunjal, and G. Coffin, "Adoption of new technologies in Ethiopian agriculture: the case of teguletbulga district, shoa province," Agricultural Economics, vol. 4, no. 1, pp. 27-43, 1990.

[38] A. D. Kehinde and R. Adeyemo, "A probit analysis of factors affecting improved technologies dis-adoption in cocoa-based farming systems of southwestern Nigeria," Int J Agric Econ, vol. 2, no. 2, pp. 35-41, 2017.

[39] S. A. Sinyolo, S. Sinyolo, M. Mudhara, and C. Ndinda, "Gender differences in water access and household welfare among smallholder irrigators in msinga local municipality, South Africa," Journal of International Women's Studies, vol. 19, no. 5, pp. 129-146, 2018.

[40] M. Noltze, S. Schwarze, and M. Qaim, "Farm diversity and heterogeneous impacts of system technologies on yield, income and poverty: the system of rice intensification in timor leste," in Proceedings of the 2012 International Association of Agricultural Economists, Foz do Iguacu, Brazil, August 2012. 